\title{
Literature Review of Parenting Style to Support the Development of Adolescent Identity
}

\author{
Enung Hasanah ${ }^{1}$, Zamroni ${ }^{1}$, Achmad Dardiri ${ }^{1}$, Setyabudi Indartono ${ }^{1} \&$ Supardi $^{2}$ \\ ${ }^{1}$ Education Science, Post Graduate, Yogyakarta State University, Indonesia \\ ${ }^{2}$ Social Science, Post Graduate, Yogyakarta State University, Indonesia \\ Correspondence: Enung Hasanah, Education Science, Post Graduate, Yogyakarta State University, Karang \\ Malang No 1, Yogyakarta, Indonesia. Tel: 68-12-2696-1900. E-mail: enung.hasanah2016@student.uny.ac.id
}

Received: April 12, $2018 \quad$ Accepted: April 24, $2018 \quad$ Online Published: May 29, 2018

doi:10.5539/ass.v14n6p157 URL: https://doi.org/10.5539/ass.v14n6p157

\begin{abstract}
The purpose of this literature review is to identify the pattern of family care to support the development of adolescent identity. The results of the literature review show that the pattern of parenting that is able to optimize the identity of adolescents is authoritative parenting pattern. Parents are believed to be more democratic in communicating, giving adolescent independence to think and act about something that concerns their life, and put the youth as the center of family education.
\end{abstract}

Keywords: parenting, adolescent, self identity

\section{Introduction}

In the 21 st century, deviation of adolescent behavior is still a complex problem that has not found a solution. Various adolescent negative behaviors, such as externalization actions (Bushment et al., 2016; Mahajan, 2010, Ormel et al., 2005; Cutulli et al., 2013), school gangs (Issurdat, 2011), bullying (Yen, 2010), and juvenile pregnancy cases (WHO, 2004), of which about 16 million adolescent girls give birth annually (WHO, 2014), have become a concern of the world community.

Youth behavior problems can't be separated from the influence of family parenting (Somer, 2010; Hann \& Borek, 2001). The family is foremost environment in terms of behavioral development (Somer, 2010; O'Connor \& Scott, 2007). Problematic families i.e lack of parental concern for children, parents who too often break their promises, overly harsh but inconsistent disciplinary planting, all of which are identified as risk factors for the development of social behavior problems of adolescent (Hann \& Borek, 2001), especially in big cities.

Adolescence is a normative crisis, i.e. a normal phase of increased conflict, which comes about from uncertainty about their identity, or identity diffusion (Abbot, 2001). Self-identity is known as a predictor of adolescent behavior (Hamilton \& White, 2008). Thus, the process of adolescent growth of determining identity is a very important part of their behavior development. It because the mistake in determining self identity cause deviation from teen social behavior (Mahajan, 2010; Hadisiwi \& Suminar, 2013).

Self identity is a very complicated construct. There is no single consensus on what and how to self identify. Based on the psychosocial theory (Salkind, 2014) that self-identity (self-image in various social roles) is formed as a result of the interaction between basic biological needs and its disclosure as social actions. Other points of life span theory view (Santrock, 2011) show that self-identity is a self-portrait of a person included in this section is the identity of a career (job), political identity (conservative, liberal, or middle way), religious identity (spiritual beliefs of a person) single, married, or divorced), intellectual identity (achievement achieved), and sexual identity (whether heterosexual, homosexual, or bisexual). In adolescence is a period of sexual exploration and experimentation, sexual fantasies and reality, combining sexuality into one's identity. In the phase of adolescent, (Rawlins, 1992) identity is related to the image they feel and the image that people respond to and see through the various experiments and mistakes they make. It helps teenagers to understand themselves. Therefore, adult supports are needed to foster teenagers find their own identities in accordance with their natural nature.

Research on the effects of family care on youth output has been widely practiced in various countries, and is acknowledged by its correlation. Research conducted by Singh \& Udainiya (2009) shows significant effects of 
the type of family and gender on self-efficacy. The interaction between family type and gender was also found to be significant. The results of Tam et al. research, shows that authoritative parenting has a positive effect on adolescent development, especially self efficacy (Tam et al., 2012). Other research (Abrheim, 2014) showed that the style and practice of parenting and adolescent self-concept are closely related in teen psychosocial development. But, although there is broad consensus about the effects of childcare practices on adolescent identity development, many questions about what affects teens care patterns in each family remain unanswered. Especially the issue of variability in the effects of parenting as a function of the teen's cultural background for they identity development (Darling \& Steinberg, 1993). This phenomenon encourages the need to explore how parenting can help teenagers build their own identity according to their potential from the adolescent's view.

\section{Life Span Development Theory}

Baltes, Reese, \& Nesselroade (1997) states that the psychology of human lives development is needed to answer questions focused on describing, explaining, and modifying processes to produce the expected output. In Baltes's view, it is important to understand that human development is built on biological, sociocultural, and cooperative factors (Santrock, 2011). These three factors no one can monopolize in the process of adolescent development, but influence each other. This means that the development of adolescents is the result of interaction and cooperation between genetically derived factors/traits, social environment, and individual innate factors.

Physically, teenagers will experience a change (Santrock, 2011). Three things physical changes are puberty, brain changes, and sexuality. The changes that occur in adolescent boys or girls are characterized by the presence of puberty. However, it is difficult to show early and late puberty. But the changes in their height and weight, is the most visible sign of sexual maturation.

Santrock (2011) said that the development of the brain in adolescence tends to rapid growth. Adolescents have an increased ability to process information. But, despite advances in the development of the prefrontal cortex - the highest level of the frontal lobes involved in reasoning, decision making, and self-control, the prefrontal cortex is not completed until 18-25 years. While the amygdala (emotional chair) arrives earlier than the prefrontal cortex. So that although teenagers are able to have very strong emotions, their prefrontal cortex is not well developed to the point where they can control it. The change of adolescent's brain causes adolescents to enter a period of transition. At this time they tend to experience confusion in determining identity. Hence, (Rubia, 2000) the teens are more aggressive and always want to try new things.

Santrock (2011) described changes that take place in adolescents' relationships with their parents. The effectively monitoring on the adolescent's development is as a key aspect of the managerial role of adolescence parenting. Parents conduct adolescents' behavior control in supervising choice of social settings, activities, friends, and academic efforts. The adolescents' disclosure to parents about their whereabouts is linked to positive adolescent attitude. Adolescents tend to gain an autonomy from their parents. However many parents seem difficult to handle teen autonomy drives and manage them productively. The different perspectives of teenagers and their parents sometimes promote the parents expectation is delivered in a not appropriate way that in turn teenagers interpreted differently and vice versa. As a result there was a misunderstanding, which led to conflict among them. However, the increase of conflict can serve a positive developmental function to promote autonomy and identity.

\section{Ki Hadjar Dewantara's Theory of Family Education for Teens}

Ki Hajar Dewantara, known as the father of Indonesian education, has his own view of special education of family education for adolescents. In Dewantara's view, the family is the best place to conduct individual and social education (Dewantara, 1977). The ideal education is education that liberate the education process that seeks to help the child to grow as his nature, to be as the potential that he has. He insists that liberate education contains three things ie independent, not dependent on others, and self-regulating.

Adolescence is a period of transition from child to maturity, so that at this time matches the way of educating behavior (self discipline) and the experience of inner birth (nglakoni=doing, ngroso=feeling, and believing) (Dewantara, 1977). This means how to educate the right teenager is to let the teen decide what to do, allowing the teenagers to reflect on their own experiences, and need dialogue, not just be observed or arranged as a childhood. The concept is in line with Freire's statement (Freire, 2011) that dialogue is important. Without dialogue, there will be no communication, and without communication there will be no real education. Human dialogue must be based on sensitivity to the innate ability to find self identity

\section{Baumrind Theory of Foster Parenting}

Parenting style as a psychological construction is a standard strategy in parenting (Arulsubila \& Subasree, 2016; 
Kordi \& Baharudin, 2010) are those who provide primary care to children. They may their biological parents, adoptive parents, grandparents, other families, or adult friends who protect, care for, and nurture children to be a good and successful in their life (Tomlinsom \& Andina, 2015).

The relationship between parents and their children promotes a process of transformation of knowledge, attitudes and skills through direct and indirect interaction. It is a social process that aims to socialize as a form of parental responsibility to the child. Based on Baumrind's opinion, parents are responsible to contribute the development of character and ethical competence of their children through their socialization efforts Baumrind \& Thompson, 2002). Baumrind categorized parenting based on two dimensions of parenting behavior i.e. demandingness and responsiveness (Darling, N., \& Steinberg, 1993; Bibi et al., 2013). Baumrind (1996) conceptualizes parenting into 3 forms, namely authoritative, authoritarian, and permissive parenting style. Authoritative parents guide children's activities in a rational, problem-oriented way. They encourage giving and taking verbal, sharing with children with reason for their policies, and asking for refutation when he refuses to adjust. Parents appreciate expressive and instrumental attributes, both volition and discipline. Whereas authoritarian parents try to shape, control and evaluate children's behavior and attitudes according to established standards of conduct, usually an absolute standard, motivated theologically and formulated by higher authorities. However, permissive parents try to behave helplessly, acceptor and affirmative toward the child's drives, desires, and actions. They consult children about policy decisions and provide explanations for family rules. Parents make few demands for household responsibilities and orderly behavior. They present itself to the child as a source for him to use as he wishes, not as an ideal for him to imitate, or as an active agent responsible for shaping or changing his ongoing or future behavior (Baumrind, 1996).

\section{Parenting and Adolescent Self Identity}

Life span development theory and Ki Hadjar Dewantara's Educational Theory assume that adolescence is a transition from childhood to adulthood. However those perspective have difference focus of the analysis. Life span theory uses an integrative approach and point of view in showing the characteristics of adolescents (puberty, brain changes, and sexuality), while Dewantara sees teenagers from the potential possessed character, mind, intellect, and physical mind which need to be developed comprehensively.

Those theories agree that the development of a teenager's identity, is the result of the interaction between natural talent and the process of parent/adult guidance. Hence, in the condition of teenagers who are all volatile and tend to full of desire to try new things in his life, the role of parents is still needed. Previous study found that the process of personality growth and identity formation in adolescence is greatly influenced by the quality of parent-child relationships (Arulsubila \& Subasree, 2016).

How to educate teenagers is not the same as educating children. As it is said that adolescents already have the ability to think (Santrock, 2011), and it's time to do self-discipline (Dewantara, 1977), so it should be treated as the subject of his own life. Teens need to be given the opportunity to express their will and act according to their needs. Adolescents need an education that liberates and builds self-reliance.

The liberating substance of education is contained in a type of authoritative pattern (Baumrind, 1996; Bibi et al., 2013) where authoritative parents direct youth activities in a rational, problem-oriented way. Parents encourage communication, share with children using reason behind their policies, and ask for refutation when he refuses to conform (Baumrind, 1996). An authoritative parenting style prioritizes dialogue in parenting.

In authoritative parenting, adolescents act as educational subjects, so every teenager has to understand what he really wants. Teenagers must see themselves as being who has a natural desire and have an obligation to respect others, (White, 2010) the individual is responsible for defining his own life. Correspondingly, individuals are responsible for their own knowledge (Gutek, 1974). Various empirical evidence proves that authoritative parenting can develop adolescent identity, either developing self esteem (Sharma \& Pandey, 2015), developing self-efficacy and well-being of adolescents (Sing \& Udainiya, 2009; Tam et al., 2012), and Psychosocial Development of Adolescents (Solfema, 2013; Abrhiem, 2014; Allen et al., 1998).

In the process of building adolescent identity, authoritative parenting patterns prove to be the best. The key to the authoritative success of parenting is the mutual trust and respect between children and parents, cause according to Baumrind (1967) that in the Authoritative parenting styles tend to make teenagers happier, have good emotional and regulatory control, and have confidence in their ability to learn new skills. The indicator of mutual trust and respect in authoritative parenting is the existence of a democratic communication process between parents and their adolescents (Steinberg, 1991). Both teenagers and parents alike have the right to express their own opinions for decision-making. Parents continue to exercise behavioral control without intimidating, through a two-way communication process, showing affection, responsiveness, consistency, and commitment. 
In summary, the link between life span theory, Dewantara theory, and Baumrind authoritative parenting theory about parenting that can help build adolescent identity can be seen in Figure 1 below:

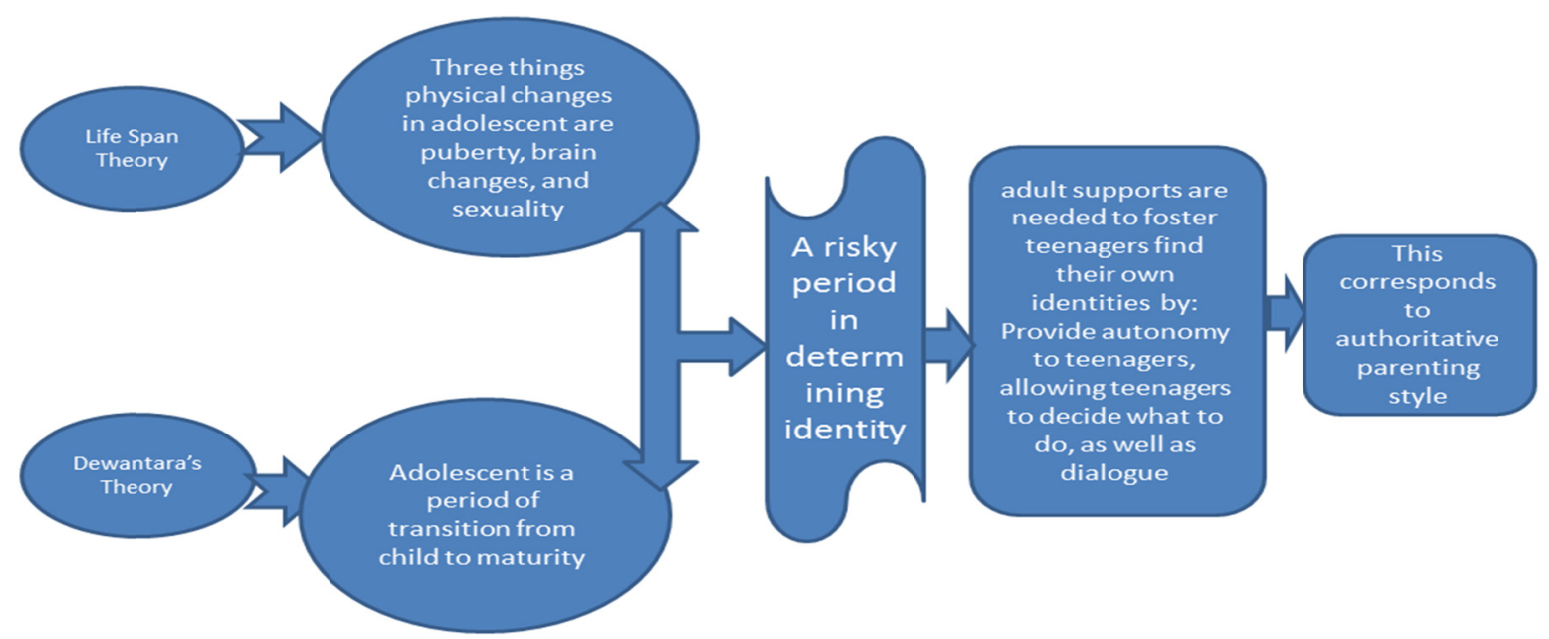

Figure 1. Parenting Style to Support the Development of Adolescent Identity

\section{Acceptability of Authoritative Parenting in Asian Culture}

In Asian cultures, teenagers are more required to succeed in school by their parents. Parents as well as children in Asian cultures have a strong belief that hard work in school will bring long-term benefits to Abbot (2001). That belief, adding to the burden on Asian teenagers because they have to accept the pressure to always excel from parents, must also meet the unrealistic expectations of their teachers. These conditions affect the process of familiarizing parents, family parenting, and expectations of parents to their children (Lynch \& Hanson, 2003). The results of Kordi \& Baharudin (2010) found that authoritative parenting style has the greatest influence on achievement of children. However, in this case there is an inconsistency between Asian and American students, where Asian students tend to be academically successful if their parents have an authoritarian parenting style. These finding suggest that for Asians, authoritative parenting style can possibly have a different cultural meanings.

\section{Conclusion}

In theory, it can be seen that how to take care of adolescents need a different approach with parenting children. Teenagers already have the ability to think and have their own desires about what he will accomplish in his life. To that end, parents (including teachers) need to understand the character of adolescents and be able to listen to what teenagers want.

In adolescence, conflicts between adolescents and the elderly tend to increase. Adolescence becomes an important part for children to gain freedom from parents as they learn something new in search of self identity. Therefore, the proper way to educate teenagers is that parents should give space for thinking and acting for teenagers as well as engaging in dialogue with them. Parents need to change the evaluation emphasis on adolescents about how close their behaviors approach their parents' wants and standards, move to a more open attitude, and make effective communication to find solutions. This parenting pattern is reflected in authoritative parenting that gives teens the freedom to think and act about something that concerns their lives, and to place young people as the center of family education. This is necessary to help teenagers to more easily determine their identity, according to their potential.

\section{References}

Abbot, T. (2001). Social and personality development. New York: Routledge.

Abrhiem, T. H. (2014). The role of parenting styles in psychosocial development of adolescents. Business and Management Review, 3(11), 47-52. Retrieved from http://www.businessjournalz.org/bmr.

Allen, J. P., Moore, C., Kuperminc, G., \& Bell, K. (1998). Attachment and adolescent psychosocial functioning. Child Development, 69(5), 1406-1419. https://doi.org/10.2307/1132274

Arusubila, M., \& Subasree, R. (2016), Parenting styles influencing personality development of catering students. International Journal of Indian Psychology, 4(1), 79. 
Baltes, P. B., Reese, H. W., \& Nesselroade, J. R. (1997). Life Span Developmental Psychology. Introduction to Research Methods. Lawrence Erlbaum Associates, Publisher.

Baumrind \& Thompson. (2002). The ethics of parenting. In M. H. Bornstein (Ed.), Handbook of parenting (2nd ed., pp. 3-34). United States of America: Lawrence Erlbaum Associates, Inc.

Baumrind, D. (1967). Child care practices anteceding three patterns of preschool behavior. Genetic Psychology Monographs, 75(1), 43-88.

Baumrind, D. (1996). Effects of authoritative parental control on child behavior. Child Development, 37(4), 887-907. https://doi.org/10.2307/1126611

Bibi, F., Chaudhry, A. G., Awan, E. A., \& Tariq, B. (2013). Contribution of parenting style in life domain of children. IOSR Journal of Humanities and Social Science (IOSR-JHSS), 12(2), 91-95.

Bushman, B. J., Newman, K., Calvert, S. L., Downey, G., Dredze, M., Gottfredson, M., ... Webster, D. W. (2016). Youth violence: What we know and what we need to know. American Psychologist, 71(1), 17-39. https://doi.org/10.1037/a0039687

Cutuli, J. J., Gillham, J. E., Chaplinc, T. M., Reivichd, K. J., Seligman, M. E. P., Gallopf, R. J., Abenavolig, R. M., \& Freresh, D. R. (2013). Preventing adolescents' externalizing and internalizing symptoms: Effects of the Penn Resiliency Program. The International Journal of Emotional Education, 5(2), 67-79.

Darling, N., \& Steinberg, L. (1993). Parenting style as context: An integrative model. Psychological Bulletin, 113, 487-496. https://doi.org/10.1037/0033-2909.113.3.487

Dewantara, K. H. (1977). Ki hadjar dewantara: pemikiran, konsepsi, keteladanan, sikap merdeka. jilid I Pendidikan. Yogyakarta: UST PRESS bekerjasama dengan Majelis Luhur Persatuan Tamansiswa.

Freire, P. (2011). Pendidikan kaum tertindas. Penerjemah: (Tim Redaksi. Jakarta: LP3ES, 2011)

Gutek, G. L. (1974). Philosophical alternatives in education. Ohio: Charles E. Merril Publishing Company.

Hadisiwi, P., \& Suminar, J. R. (2013). Konstruksi sosial anggota geng motor di kota Bandung. Jurnal Kajian Komunikasi, 1(1), 1-10. Departemen Ilmu Komunikasi, Fakultas Ilmu Komunikasi, Universitas Padjadjaran. https://doi.org/10.24198/jkk.v1i1.6026

Hamilton, K., \& White, K. M. (2008). Extending the theory of planned behavior: the role of self and social influences in predicting adolescent regular moderate-to-vigorous physical activity. Journal of Sport \& Exercise Psychology, 30, 56-74. Human Kinetics, Inc. https://doi.org/10.1123/jsep.30.1.56

Hann, D., \& Borek, N. (2001). Taking stock of risk factors for child/youth externalising behaviour problems. Dept. of Health and Human Services, Public Health Service, National Institutes of Health, National Institute of Mental Health.

Issurdatt, S. (2011). Gangs: A growing problem in schools. Washington, DC 20002-4241. Social Workers.org

Kordi, A., \& Baharudin, R. (2010). Parenting attitude and style and its effect on children's school achievements. International Journal of Psychological Studies, 2(2). https://doi.org/10.5539/ijps.v2n2p217

Lynch, \& Hanson. (2001). A guide for working with children and their Families: Developing cross-cultural competence (3rd ed.). Brookes: Baltimore.

Mahajan, S., Arora, A. K., Gupta, P., \& Kapoor, S. S. (2010). Adolescent violence: an emerging challenge. $J$ Punjab Acad Forensic Med Toxicol, 10(2), 97-100.

O'Connor, T. G., \& Scott, S. B. C. (2007). Parenting and outcomes for children. Joseph Rowntree Foundation.

Ormel, J., Oldehinke, A. J., Referdinand, Chahartman, C. A., Dewinter, A. F., Venstra, R., ... Verhulst, C. (2005). Internalizing and externalizing problems in adolescence: general and dimension-specific effects of familial loadings and preadolescent temperament traits, Psychological Medicine 35, 1825-1835. Cambridge University Press.

Rawlins, W. K. (1992). Friendship matters: Communication, dialectics, and life course. Aldine de Gruyter. New York. https://doi.org/10.1017/S0144686X00000143

Ries, F. (2012). Self-identity as a component of the Theory of Planned Behaviour in predicting physical activity. European Physical Education Review, 18(3), 322-334. https://doi.org/10.1177/1356336X12450792

Rubia, K., Overmeyer, S., Taylor, E., Brammer, M., Williams, S. C., \& Simmons, A. (2000). Functional frontalisation with age: mapping neurodevelopmental trajectories with fMRI. Neurosci Biobehav Rev, 24(1), 


\section{3-19. https://doi.org/10.1016/S0149-7634(99)00055-X}

Salkind, N. J. (2014). An introducion to theories of human development. CA: Sage Publication, Inc.

Santrock, J. W. (2011). Life-span development (13th ed.). New York: McGraw-Hill.

Sharma, G., \& Pandey, N. (2015). Parenting styles and its effect on self-esteem of adolescents. The International Journal of Indian Psychology, 3(1), 7.

Sing, B., \& Udainiya, R. (2009). Self-efficacy and well-being of adolescents. Journal of the Indian Academy of Applied Psychology, 35(2), 227-232.

Smetana, J. G. (2011). Adolescents, families, and social development: How teens construct their worlds. Malaysia: Toppan Best-set Premedia Limited.

Solfema. (2013). Pengasuhan orangtua, budaya sekolah, budaya masyarakat, dan empati anak usia remaja. Jurnal Ilmu Pendidikan, 19(2), 149-154.

Sommer, K. L. (2010). The relationship between parenting styles, parental reading involvement, child behavior outcomes, child classroom competence, and early childhood literacy. Faculty of the Graduate College of the Oklahoma State University in partial fulfillment of the requirements for the Degree of Master of Science.

Steinberg, L., Mounts, N. S., Lamborn, S. D., \& Dornbusch, S. M. (1991). Authoritative parenting and adolescent adjustment across varied ecological niches. Journal of Research on Adolescence, 1(1), 19-36.

Tam, C.-L., Chong, A., Kadirvelu, A., \& Khoo, Y.-T. (2012). Parenting styles and self-efficacy of adolescents: malaysian scenario. Global Journal of Human Social Science Arts \& Humanisties, 12(14), 19-25.

Tomlinson, H. B., \& Andina, S. (2015). Parenting education in Indonesia: Review and recommendations to strengthen programs and systems. World Bank Studies. Washington, DC: World Bank. https://doi.org/10.1596/978-1-4648-0621-6

White, J. (2010). The aims of education restated. London and New York: Taylor \& Francis e-Library.

WHO. (2014). Adolescent pregnancy. Retrieved from http://www.who.int/reproductivehealth

WHO. (2004). Adolescent Pregnancy. Department of Child and Adolescent Health and Development World Health Organization. Geneva.

Yen, C. F. (2010). School bullying and mental health in children and adolescents. Taiwanese Journal of Psychiatry (Taipei), 24(1), 3-13.

\section{Copyrights}

Copyright for this article is retained by the author(s), with first publication rights granted to the journal.

This is an open-access article distributed under the terms and conditions of the Creative Commons Attribution license (http://creativecommons.org/licenses/by/4.0/). 